\title{
Furniture Rack Corrosion Coupon Surveillance - 2012 Update
}

\author{
J. I. Mickalonis \\ T. R. Murphy \\ C. J. Berry
}

October 2012

Savannah River National Laboratory Savannah River Nuclear Solutions, LLC Aiken, SC 29808

Prepared for the U.S. Department of Energy under contract number DE-AC09-08SR22470. 
SRNL-TR-2012-00248

Revision 0

\section{DISCLAIMER}

This work was prepared under an agreement with and funded by the U.S. Government. Neither the U.S. Government or its employees, nor any of its contractors, subcontractors or their employees, makes any express or implied:

1. warranty or assumes any legal liability for the accuracy, completeness, or for the use or results of such use of any information, product, or process disclosed; or

2. representation that such use or results of such use would not infringe privately owned rights; or

3. endorsement or recommendation of any specifically identified commercial product, process, or service.

Any views and opinions of authors expressed in this work do not necessarily state or reflect those of the United States Government, or its contractors, or subcontractors.

\section{Printed in the United States of America}

Prepared for U.S. Department of Energy 
Keywords: Spent fuel storage, aluminum alloys, pitting

corrosion

Retention: Permanent

\title{
Furniture Rack Corrosion Coupon Surveillance - 2012 Update
}

\author{
J. I. Mickalonis \\ T. R. Murphy \\ C. J. Berry
}

October 2012

Savannah River National Laboratory Savannah River Nuclear Solutions, LLC Aiken, SC 29808

Prepared for the U.S. Department of Energy under contract number DE-AC09-08SR22470. 


\section{ACKNOWLEDGEMENTS}

The authors wish to acknowledge the following for their assistance in the metallurgical evaluations: D. Z. Nelson, T. Reown, V. B. Timmerman, and J. E. Ziska. 


\section{EXECUTIVE SUMMARY}

Under the L Basin corrosion surveillance program furniture rack coupons immersed for 14 years (FY2009 coupons) and 16 years (FY2011 coupons) were analyzed and the results trended with coupons exposed for shorter times. In addition, a section harvested from an actual furniture rack that was immersed for 14 years was analyzed for pitting in the weld and heat-affected-zone (HAZ) regions. The L Basin operations maintained very good water quality over the entire immersion period for these samples.

These results for FY2009 and FY2011 coupons showed that the average pit depths for the 6061 and 6063 base metal are 1 and 2 mils, respectively, while those for the weld and HAZ are 3 and 4 mils, respectively. The results for the weld and HAZ regions are similar to coupons removed during the period of FY2003 to FY2007. These similarities indicate that the pit development occurred quickly followed by slow kinetics of increase in pit depth. For the actual furniture rack sample average pits of 5 and 2 mils were measured for the HAZ and weld, respectively.

These results demonstrate that pitting corrosion of the aluminum furniture racks used to support the spent fuel occurs in waters of good quality. The corrosion kinetics or pit depth growth rate is much less that 1 mil/year, and would not impact long-term use of this material system for fuel storage racks in L Basin if good water quality is maintained. 


\section{TABLE OF CONTENTS}

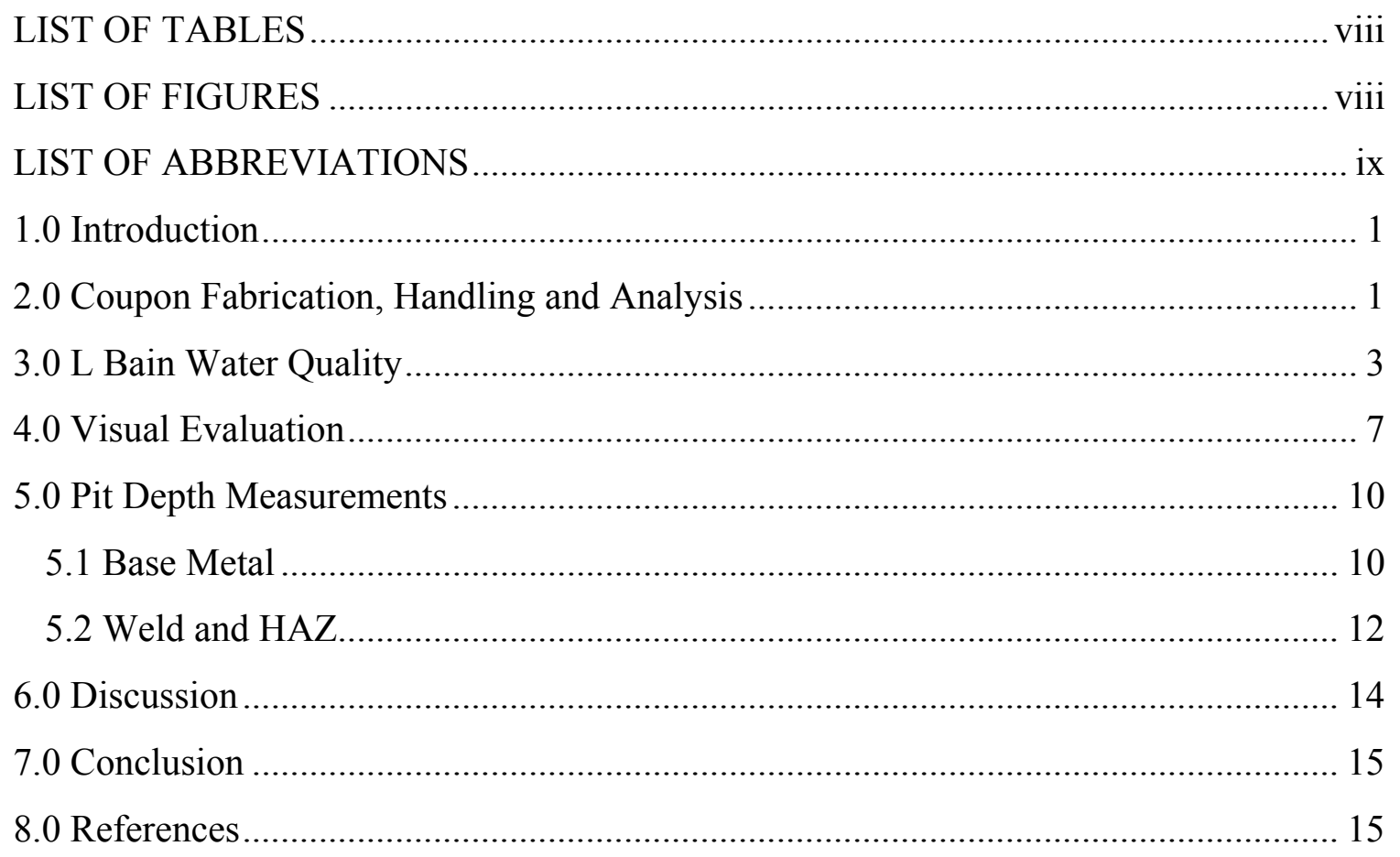




\section{LIST OF TABLES}

Table 2-1 Composition of Aluminum Alloys for Corrosion Coupons................................ 1

Table 2-2 L Basin Furniture Rack Coupon Numbering ..................................................... 2

Table 5-1 Pit Depths in Base Metal for 2009 and 2011Furniture Rack Coupons ........... 10

Table 5-2 Pit Depths in the Weld and HAZ of 2009 and 2011 Furniture Rack Coupons 13

\section{LIST OF FIGURES}

Figure 2-1 Location of furniture rack sample sectioned from actual furniture rack assembly (picture shows a spare rack not actual rack that the sample was

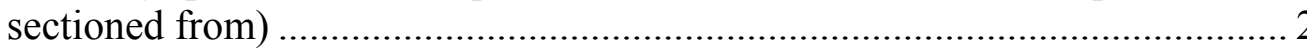

Figure 3-1 L Basin Water Quality Parameter Trends - Conductivity, pH and Cs-137 activity over the time period of 2001 through 2011 ........................................ 4

Figure 3-2 L Basin Water Quality Parameter Trends - Concentrations of $\mathrm{Cl}, \mathrm{Cu}$, and $\mathrm{Hg}$

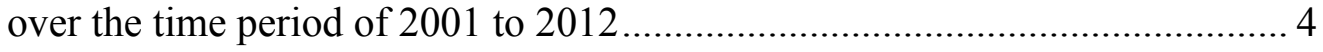

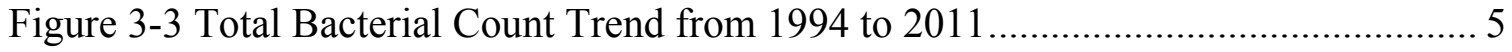

Figure 3-4 Metabolic diversity of L Basin water as measured using Biolog ${ }^{\mathrm{TM}}$ plates over

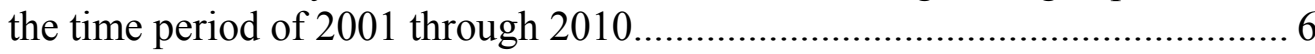

Figure 3-5 Bacterial density of viable bacteria in L Basin over the years of 2001 through 2010.

Figure 4-1 As-received condition of the furniture rack coupons removed from L Basin in (A) 2009 and (B) 2011

Figure 4-2 2009 L Basin furniture rack coupons after nitric acid cleaning: (A) after 20 minutes and (B) after 120 minutes........................................................... 8

Figure 4-3 2009 L Basin furniture rack coupon - welded 6063 U-channel - (B) is a magnified view of the encircled area in (A) showing residual oxide after nitric acid cleaning)

Figure 4-4 $2011 \mathrm{~L}$ Basin furniture rack coupons after 20 minutes in nitric acid; also shown in the figure on the right is the 6063control coupon for determining weight loss during cleaning.

Figure 4-5 L Basin furniture rack coupons after cleaning in nitric acid: (A) 2011 welded 6061 plate, stereo-micrograph (75x), (B) 2011 welded 6063 U-channel, stereo-micrograph (75x), (C) 2009 welded 6061 plate, $35 \mathrm{~mm}$; and (D) 2009 welded 6063 U-channel, $35 \mathrm{~mm}$.

Figure 5-1 Pitting observed in 6063 control coupon cleaned in nitric acid with 2011 furniture rack coupons $(200 x$, arrow indicates pit) 
Figure 5-2 Pit morphologies in 2011 furniture rack coupons after cleaning in nitric acid: (A) rounded, symmetrical pit on AB40333A-4A and (B) angular, directional pit on AB40333A-4B (200x)

Figure 5-3 Cumulative average and maximum pit depths from the weld and HAZ measured in 6063 U-channel and storage rack

Figure 5-4 Cumulative average and maximum pit depths from the weld and HAZ measured in 6061 plate

\section{LIST OF ABBREVIATIONS}

DOE Department of Energy

GN gram negative

GP gram positive

HAZ heat-affected zone

M\&TE measuring and testing equipment

MIC microbiological influenced corrosion

mpy mils per year

$\mathrm{N} \quad$ total pit population

ND no data

$\mathrm{P}_{10} \quad$ average pit density of 10 deepest pits

$\mathrm{P}_{\max } \quad$ maximum pit depth

$\mathrm{P}_{\mathrm{N}} \quad$ average pit density of total pit population

SEM scanning electron microscope

SRNL Savannah River National Laboratory

$\sigma_{\mathrm{N}} \quad$ standard deviation of total pit population 


\subsection{Introduction}

Furniture rack coupon surveillance, initiated in July 1995, provides an early indication of corrosion attack to the fuel storage rack materials in L Basin. The storage racks are used to support and separate fuel element containers stored in L Basin. The furniture rack coupon surveillance is part of the L Basin Corrosion Surveillance Program [5] which also includes coupon materials and configurations that provide an early indication of corrosion attack to the aluminum fuel cladding in L Basin.

Furniture rack coupons were removed from L Basin in FY2009 and FY2011 and the corrosion characterization of these coupons is reported herein. This report also presents the trending of corrosion data observed over the prior surveillance exposure periods [1-4]. A specimen harvested from an actual storage rack was also analyzed and the corrosion characteristics were compared to the surveillance coupon results.

\subsection{Coupon Fabrication, Handling and Analysis}

The furniture rack coupons were fabricated from the same heat of material used to fabricate the horizontal storage racks, namely 6061-T6 and 6063-T5 aluminum alloys. The weld filler material used was R4043. The nominal compositions are given in Table $2-1$.

The two alloys are from the family of magnesium-silicon based chemistries. The tempering conditions differ as indicated by the T5 and T6 designations. The T5 indicates the alloy was cooled from an elevated temperature during shaping and artificially aged, i.e. precipitation heat treated, to obtain desired mechanical properties and dimensional stability. The T6 designation is for material that has been solution heat treated and artificially aged.

Table 2-1 Composition of Aluminum Alloys for Corrosion Coupons*

\begin{tabular}{|c|c|c|c|c|c|}
\hline \multirow{2}{*}{ Alloy } & \multicolumn{5}{|c|}{ Elemental Concentration (wt\%) } \\
\cline { 2 - 6 } & Si & Cu & Mg & Cr & Fe \\
\hline 6061-T6 & 0.6 & 0.28 & 1 & 0.35 & \\
\hline 6063-T5 & 0.4 & & 0.7 & 0.1 & 0.35 \\
\hline R4043 & 6.0 & 0.3 & 0.05 & & 0.8 \\
\hline
\end{tabular}

* R4043 is the weld filler rod used to place a weld in the center of the coupon

The 6061 surveillance coupons were fabricated from plate and had dimensions of 4 in by 2 in by 0.25 in. The 6063 coupons were from extruded U-channel and have dimensions of 4 in by 0.625 in by 0.125 in. For welded coupons, a single weld bead, approximately 0.25 in wide, was deposited. Coupon welding was performed using gas tungsten arc welding by the fabricator of the furniture rack assemblies. In Table 2-2, the coupon numbering is given along with the alloy composition and weld condition.

The furniture rack coupons were placed at four locations in the horizontal bundle and bucket storage area of L Basin in 1995. Five coupons were strung together as a set for 
removal at a scheduled time. Multiple sets of coupons were placed at each of the four locations. The 2009 and 2011 coupons were removed August 24, 2009 and July 27, 2011 , respectively. Four sets of five furniture rack coupons remain in the basin for withdrawal at a future date.

Table 2-2 L Basin Furniture Rack Coupon Numbering

\begin{tabular}{|c|c|c|c|}
\hline Alloy & Welding & $\mathbf{2 0 0 9}$ & $\mathbf{2 0 1 1}$ \\
\hline 6061-T6 & No & AB40333A-7A & AB40333A-4A \\
\hline & No & AB40333A-9C & AB40333A-4C \\
\hline & Yes & AB40333A-7D & AB40333A-4D \\
\hline 6063-T5 & No & AB40333A-7A & AB40333A-4B \\
\hline & Yes & AB40333A-7D & AB40333A-4F \\
\hline
\end{tabular}

With the 2009 coupons, a welded section from an actual furniture rack assembly pulled from L Basin was also sent to SRNL for analysis. Figure 2-1 shows the location on the furniture rack that the sample was taken. The furniture rack was in the basin for 14 years. The analysis will be used to benchmark the furniture rack coupon data.

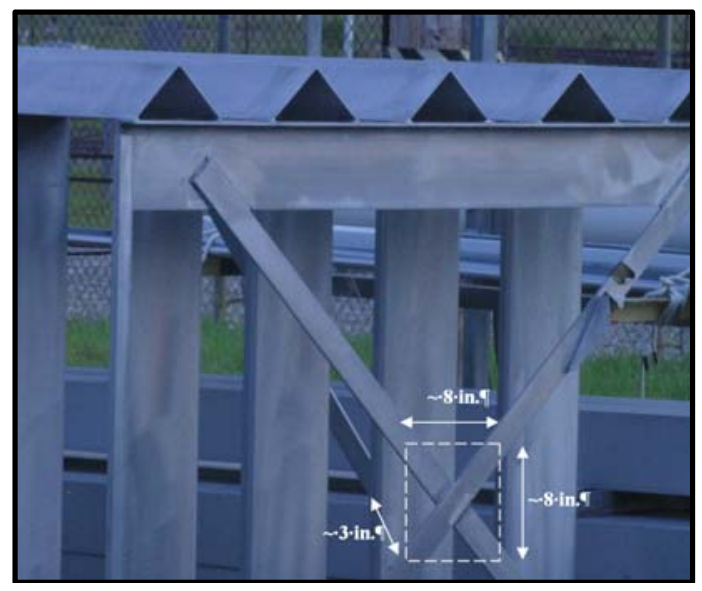

Figure 2-1 Location of furniture rack sample sectioned from actual furniture rack assembly (picture shows a spare rack not actual rack that the sample was sectioned from)

The coupons were bagged out when removed from the basin. Residual water adheres to the surfaces of the coupons. The coupons were transported to SRNL for analysis where coupons were allowed to dry naturally in a hood. The corrosion process continues until the moisture has fully dried. The total time from basin removal to fully-dry, including specimen crevices, is estimated to have been up to 1 year. The results were not corrected for this exposure since the surveillance data has shown these rates to be low [10].

The analysis for the furniture rack coupons is described in the corrosion surveillance program plan [5]. The primary elements are photographic documentation both before and after cleaning of corrosion/oxidation products, cleaning in concentrated nitric acid, 
and characterization of pitting by pit depth and size measurements. The photographs were taken using a $35-\mathrm{mm}$ camera. Photographs of specific pits were taken using a Nikon DS-Vil digital sight camera attached to a Nikon microscope. The full set of photographic data is contained in Laboratory Notebook SRNL-NB-2009-00132.

The furniture rack coupons were cleaned in concentrated nitric acid at room temperature. The coupon cleaning differed for the 2009 and 2011 furniture rack coupons. For 2009 coupons, the coupons were cleaned three times for periods of 20,30 and 30 minutes since the oxide was difficult to remove. For 2011 coupons, the coupons were cleaned for two 10-minute periods. Although all the oxide was not completely removed, additional cleaning was not performed due to the cumulative corrosion of aluminum in repeated exposure to concentrated nitric acid. The oxide in the heat affected zone (HAZ) of the welded coupons was the most difficult to remove.

A control coupon, not exposed to basin water, was used during the cleaning of the 2011 coupons to measure the aluminum corrosion rate during cleaning. The 6061 coupon lost $0.5 \mathrm{mg}$ over a 20 -minute cleaning period, which translates to a corrosion rate of approximately 66 mils per year (mpy). Extended cleaning of the furniture rack coupons could lead to further pitting attack and general metal loss of the coupons.

Pit depths were measured on a Nikon MM-400 measuring microscope with a Nikon SC3E1 digital counter. EMAX software by Excel Technologies was used for data processing of the depth measurements. The protocol was to scan the coupon at a 100x magnification for identifying pits of measureable depth and then measure the pit depth at a $200 \mathrm{x}$ magnification. This protocol has been developed over the last several years for making pit measurements on the surveillance coupons and was established in the surveillance program plan [5].

\subsection{Basin Water Quality}

The L Basin water quality has been well controlled over the furniture rack coupon exposure. The L Basin Water Chemistry Control Program establishes limits to control the basin water activity and to minimize corrosion of the fuels, bundles, and associated handling and storage equipment. The $\mathrm{pH}$ and conductivity limits are: $5.5 \leq \mathrm{pH} \leq 8.5$ and conductivity $<10 \mu \mathrm{S} / \mathrm{cm}[6]$. The basin water $\mathrm{pH}$ and conductivity fell within these limits. The data over the time period of 2001 to 2011 is given in Figure 3-1 along with the Cs-137 activity. The spikes in conductivity and Cs-137 activity correspond to the addition of fuels to the basin as well as operational activities such as maintenance to a deionizer valve and a change in the building AC. The Cs-137 limit, which was established at $<500 \mathrm{dpm} / \mathrm{ml}$, was exceeded only briefly in 2003 after the addition of failed fuels from RBOF [6].

Elemental species are also regulated by the L Basin Water Corrosion Control Program, including $\mathrm{Cl}(\leq 0.1 \mathrm{ppm}), \mathrm{Hg}(\leq 0.014 \mathrm{ppm})$, and $\mathrm{Cu}(\leq 0.1 \mathrm{ppm})$. Over the years the furniture rack coupons were exposed in L Basin, the chloride concentration was the only species to meet or exceed its limit as shown in Figure 3-2. Most of the higher values were obtained during the early years of the exposure. 


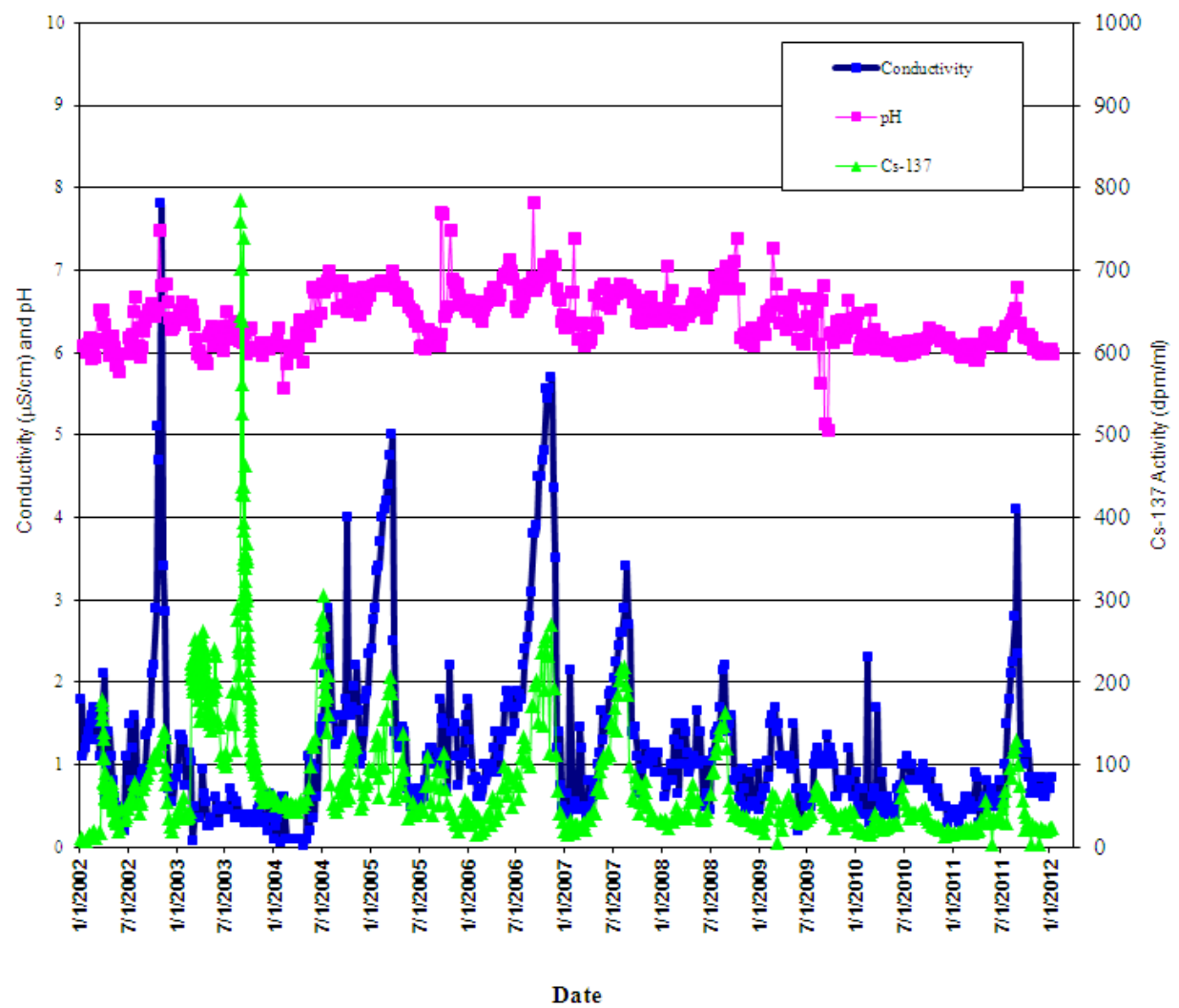

Figure 3-1 L Basin Water Quality Parameter Trends - Conductivity, pH and Cs-137 activity over the time period of 2001 through 2011

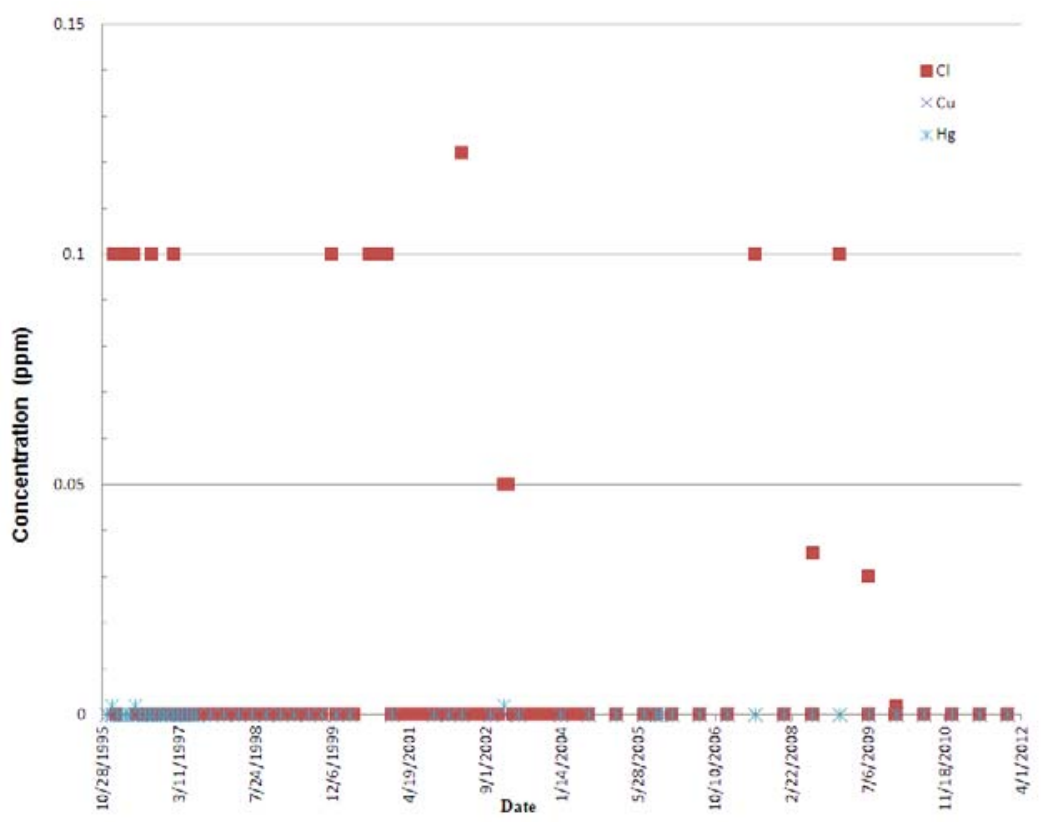

Figure 3-2 L Basin Water Quality Parameter Trends - Concentrations of $\mathrm{Cl}, \mathrm{Cu}$, and Hg over the time period of 1995 to 2012 
Another measure of water quality is the microbial activity that is documented through the Microbial Monitoring Program [7]. A number of microbial parameters have been trended since 2001, including bacterial densities by a total direct count, Biolog ${ }^{\mathrm{TM}}$ readings, and viable bacterial density, as measured using a MICKit ${ }^{\mathrm{TM}}$. Details of these techniques may be found in Reference 7. This information is used to provide a warning system to prevent microbiological influenced corrosion (MIC) from becoming an operational concern. General trends for all measured microbial parameters have decreased or stayed relatively low. These trends indicate that operation of the basin has not facilitated the growth of planktonic bacteria and that MIC is not a significant factor for the furniture racks or the coupons exposed since 1995.

Total direct counts are made of both viable and non-viable bacteria present in a basin water sample. After a basin water sample is heat fixed to a slide and stained, the stained microbial cells are counted using a Zeiss epifluorescent microscope. Total direct counts in the L Basin, including both viable and non-viable bacteria have trended downwards since 2008 as shown in Figure 3-3. The average density of bacteria in the water samples since 2008 is less than half that average for the time period since 2001 .

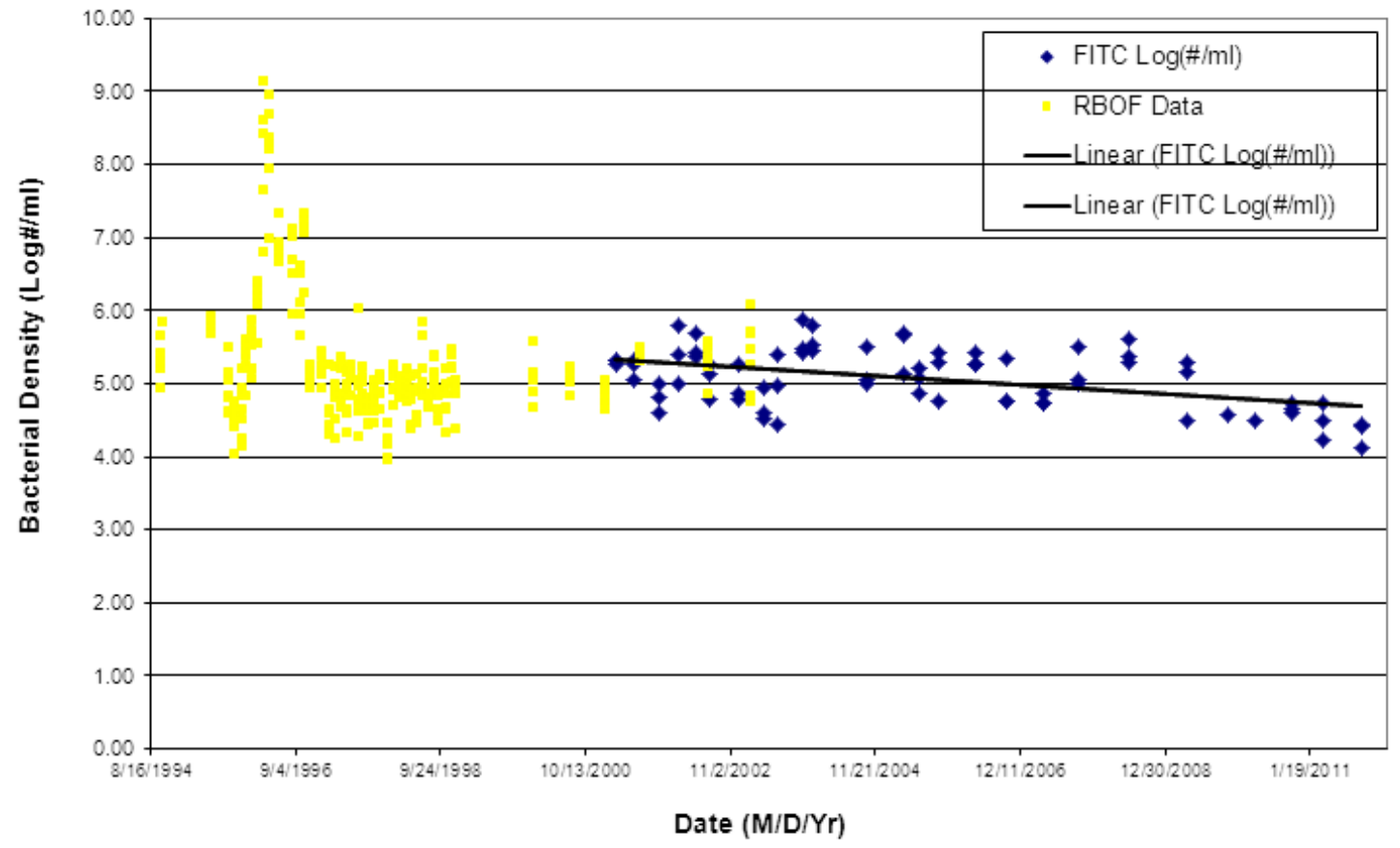

Figure 3-3 Total Bacterial Count Trend from 1994 to 2011

A measure of the microbial diversity is given by Biolog ${ }^{\mathrm{TM}}$ plates, which has shown a decreasing trend since its use initiated in 2001 as shown in Figure 3-4. The plates are used to differentiate aerobic bacteria between gram negative (GN) and gram positive (GP) species, which indicates a difference in the cell membrane structure. The plates have 95 wells with different organic substrates that will activate an indicator dye due to enzyme reactions of the microbes. A large number of positive wells indicate increased 
physiological diversity and activity in the microbial population. Scrapings from pins exposed to the L Basin water were also used to inoculate the wells. Over ten years the metabolic diversity of bacteria in the water samples has decreased. The measured metabolic diversity reached minimum values from 2006-2008 but has increased some since then, although 2011 results are not included in Figure 3-4.

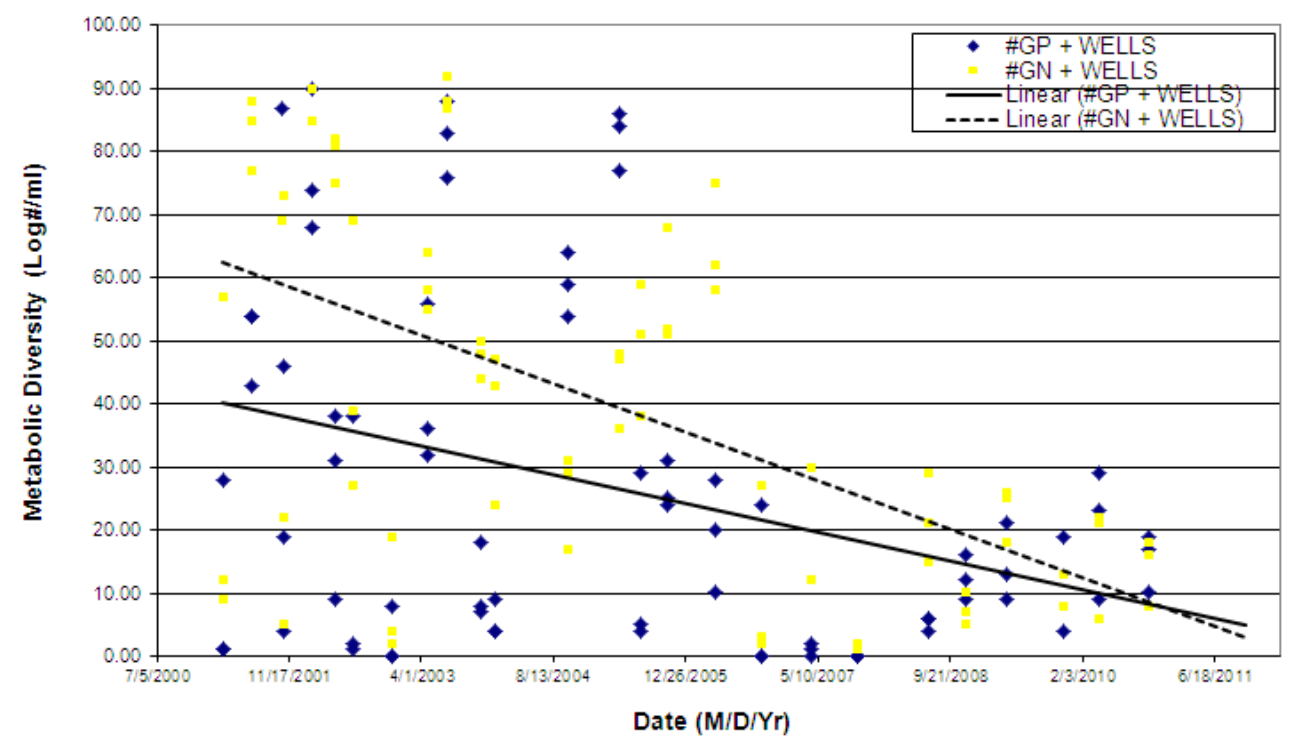

Figure 3-4 Metabolic diversity of L Basin water as measured using Biolog ${ }^{\mathrm{TM}}$ plates over the time period of 2001 through 2010

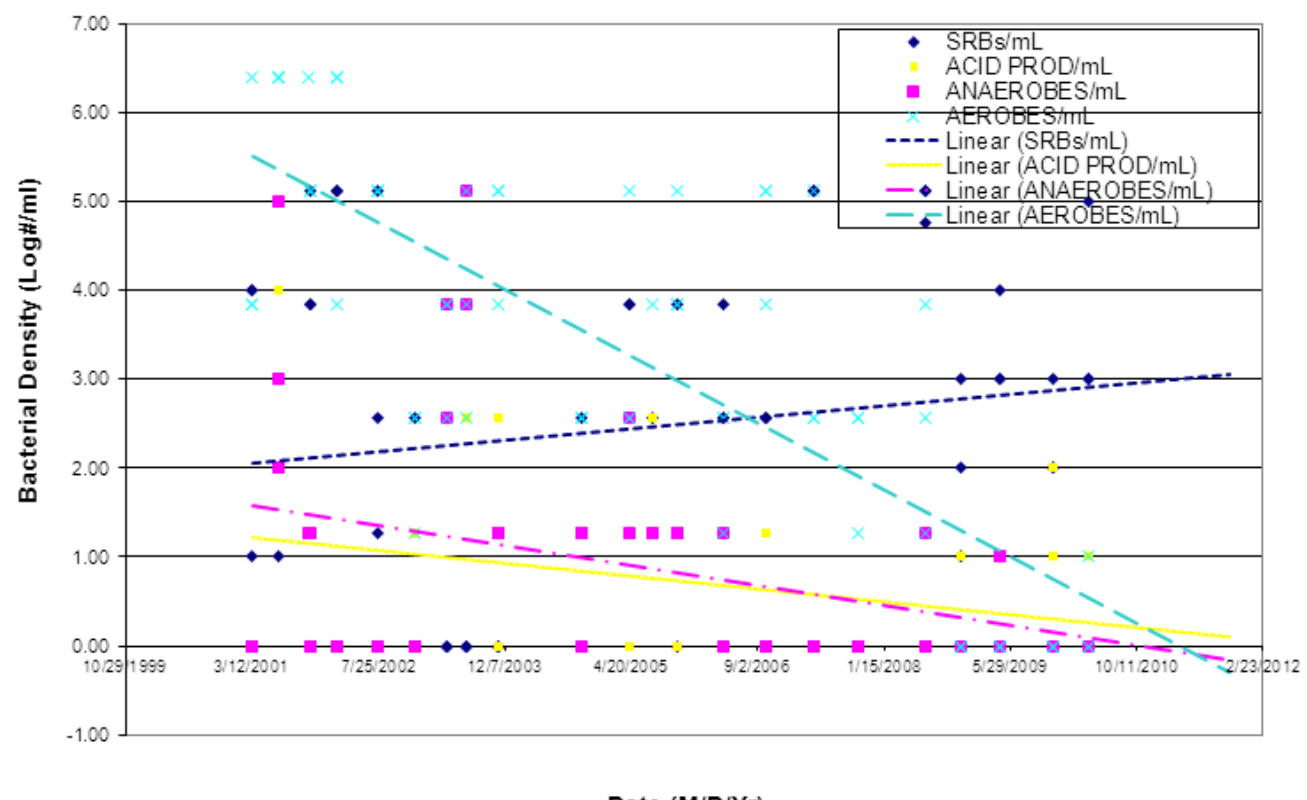

Figure 3-5 Bacterial density of viable bacteria in L Basin over the years of 2001 through 2010 
Viable counts of aerobic, anaerobic, sulfate-reducing, and acid-producing bacteria were determined using the commercially available MICKit ${ }^{\mathrm{TM}}$. The results and trends of viable bacteria showed a decrease for all groups except sulfate-reducing bacteria which have increased by one order of magnitude over nine years of sampling. These trends are shown in Figure 3-5 through 2010.

\subsection{Visual Evaluation}

The furniture rack coupons build up a non-uniform aluminum oxide layer on the surface during exposure. The as-received condition is documented in Figure 4-1 for the coupons removed in 2009 and 2011, which is similar to furniture rack coupons from 2002 onward [1-3]. The non-uniform nature of the oxide is noted by variation in the coloring, which gives a mottled gray appearance. A heavy oxide can also be observed in the HAZ of the weld as noted by the whiteness around the weld. Also noted on the coupons were rustcolored spots, which are indicative of ferrous corrosion products or residual particles that settled on the coupons during exposure.
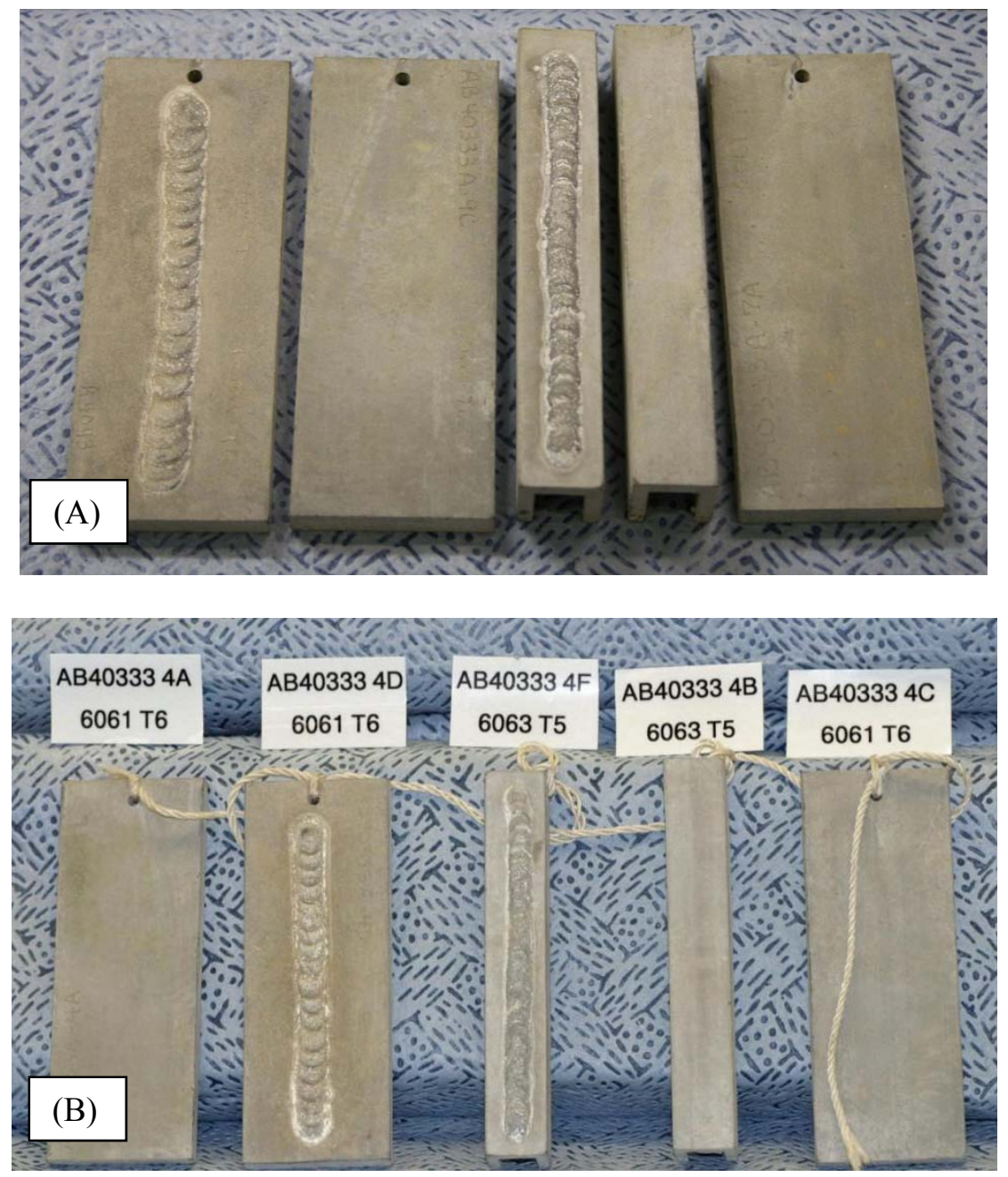

Figure 4-1 As-received condition of the furniture rack coupons removed from L Basin in (A) 2009 and (B) 2011 
The coupons were cleaned in concentrated nitric acid at room temperature for variable times as noted previously. For 2009 and 2011, the total times of immersion were 120 and 20 minutes, respectively. For 2009 coupons, much of the oxide was removed by the extended time in the nitric acid as shown in Figure 4-2. The photographs in this figure taken after 20 and 120 minutes of cleaning show the patchy removal of the oxide during the cleaning process. At the conclusion of cleaning, oxide still adhered to areas especially at the HAZ and the weld as shown in Figure 4-3 for the welded $6063 \mathrm{U}$ channel coupon as well as in patches around the remainder of the coupons. The small pits that are present cannot be fully resolved at this magnification.

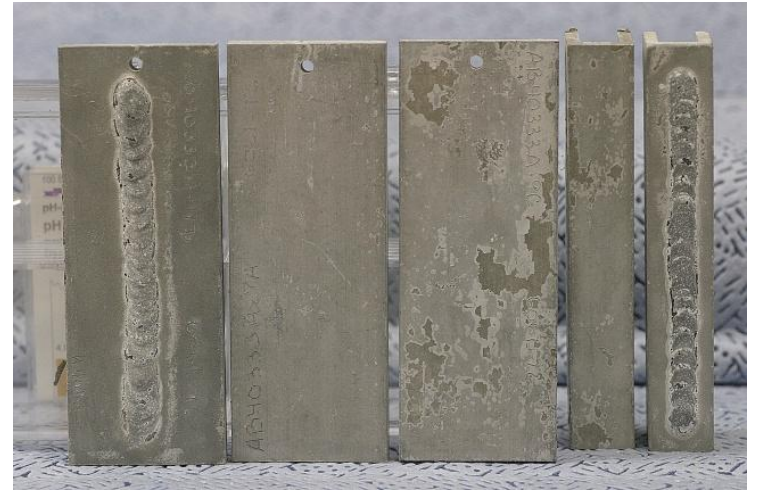

(A)

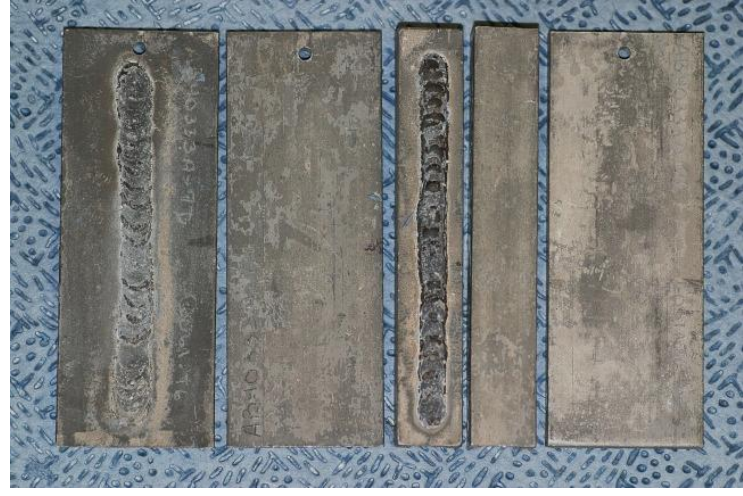

(B)

Figure 4-2 2009 L Basin furniture rack coupons after nitric acid cleaning: (A) after 20 minutes and (B) after 120 minutes

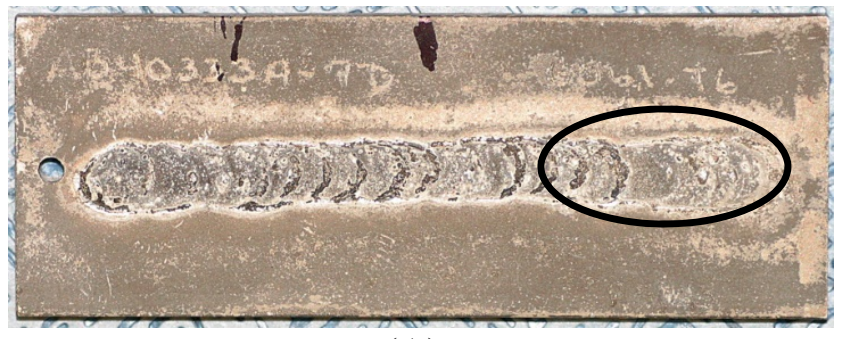

(A)

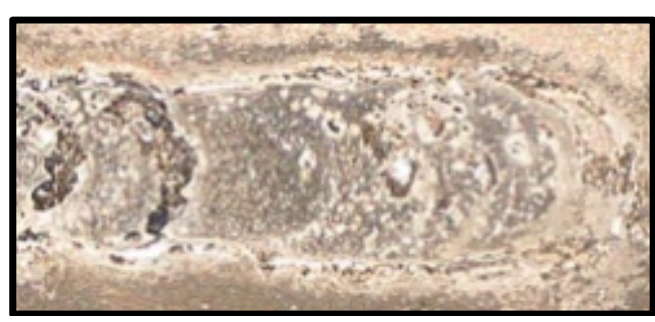

(B)

Figure 4-3 2009 L Basin furniture rack coupon - welded 6063 U-channel - (B) is a magnified view of the encircled area in (A) showing residual oxide after nitric acid cleaning

The 2011 coupons are shown in Figure 4-4 after two 10-minute cleaning periods. The coupons appear similar to those from 2009 as shown in Figure 4-2 (B). The oxide appeared to be easier to remove from the 2011 coupons than the 2009 coupons, which is part of the rationale for differences in cleaning times. 
SRNL-TR-2012-00248

Revision 0

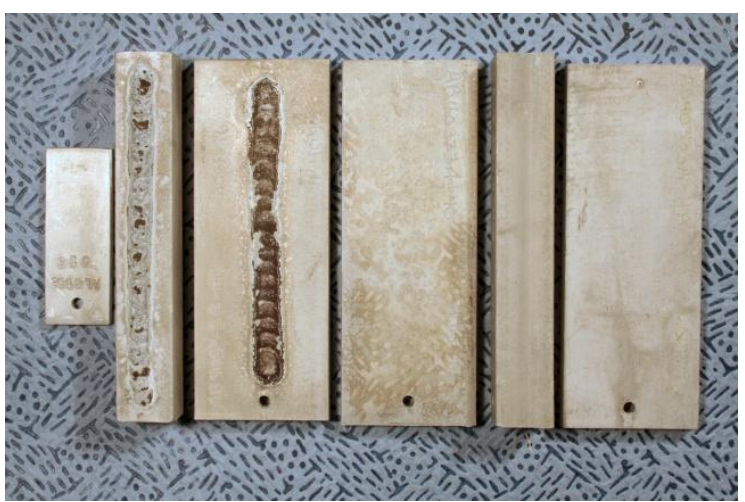

Figure 4-4 2011 L Basin furniture rack coupons after 20 minutes in nitric acid; also shown in the figure on the right is the 6063control coupon for determining weight loss during cleaning

This difference in oxide removal is especially apparent on the welded 6061 plates which are shown in Figure 4-5 (A and C) for 2011 and 2009, respectively. The welded Uchannel coupons had similar oxide coverage at the completion of cleaning (Figure 4-5 (B and D). The different oxidation characteristics could be associated with differences in the individual coupon metallurgy or localized variations in the basin chemistry.

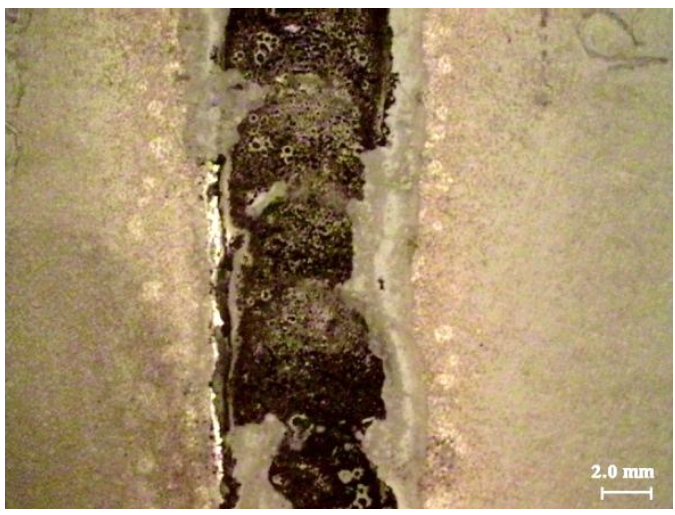

(A)

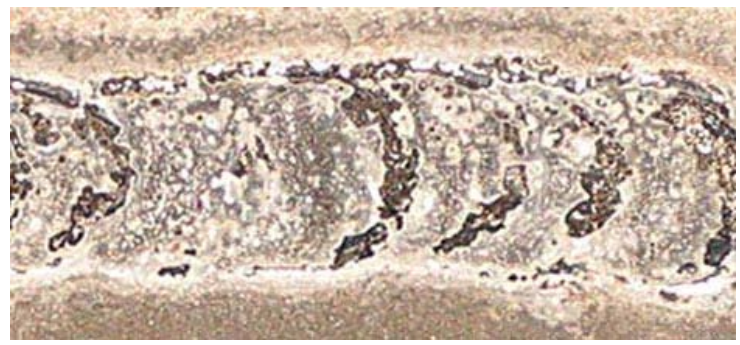

(C)

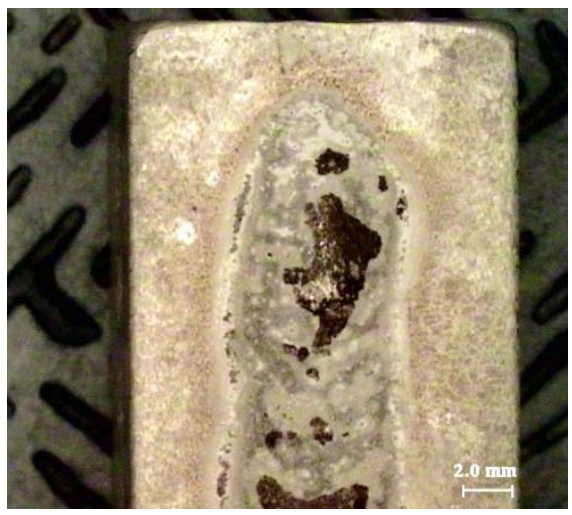

(B)

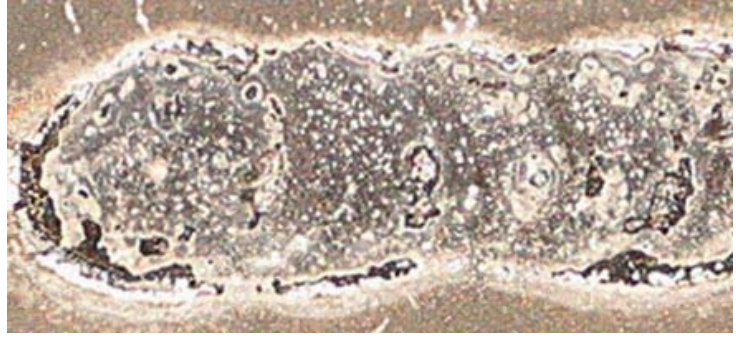

(D)

Figure 4-5 L Basin furniture rack coupons after cleaning in nitric acid: (A) 2011 welded 6061 plate, stereo-micrograph (75x), (B) 2011 welded 6063 Uchannel, stereo-micrograph (75x), (C) 2009 welded 6061 plate, $35 \mathrm{~mm}$; and (D) 2009 welded 6063 U-channel, $35 \mathrm{~mm}$ 
A 6063 control coupon was used during the cleaning in 2011. The appearance of the coupon is shown in Figure 4-4 along with the 2011 furniture rack coupons. The coupon has a degraded or tarnished appearance, especially in contrast to a coupon with a freshly prepared surface that has a shiny metallic appearance. The change in appearance of the control coupon demonstrates the degradation that the coupons experience during cleaning. This degradation or corrosion is minimized for the basin coupons because of the thick oxide layers. However, once this layer is removed the surface of the furniture rack coupon will be degraded. The corrosion rate from weight loss for the fresh surface control coupon was calculated to be equivalent to 66 mpy for the 20 -minute cleaning time.

\subsection{Pit Depth Measurements}

Pit measurements were made in the base metal, weld and HAZ of both sets of coupons. The base metal is discussed separately from the weld and HAZ since it represents the fundamental pitting resistance of the aluminum alloy.

\subsection{Base Metal}

Small, shallow pits were continued to be found on the furniture rack coupons which is similar to results from previous years [1-3]. The first documented pits in the base metal were for the FY2002 coupons, which had a pit depth of 0.5 mils [1]. For the 2009 and 2011 furniture rack coupons, the data are summarized in Table 5-1, which lists several pitting parameters, including the pit count $(\mathrm{N})$, maximum pit depth $\left(\mathrm{P}_{\max }\right.$, mils), average depth of ten deepest pits $\left(\mathrm{P}_{10}\right.$, mils), the average depth of all pits $\left(\mathrm{P}_{\mathrm{N}}\right.$, mils) and the standard deviation of all the pits depths $\left(\sigma_{N}\right.$, mils). The standard deviation of the ten deepest pits was similar in most cases to $\sigma_{\mathrm{N}}$.

Table 5-1 Pit Depths in Base Metal for 2009 and 2011Furniture Rack Coupons*

\begin{tabular}{|c|c|c|c|c|c|c|c|c|}
\hline Year & Number & Alloy & Weld & $\mathbf{N}$ & $\mathbf{P}_{\max }$ & $\mathbf{P}_{10}$ & $\mathbf{P}_{\mathrm{N}}$ & $\sigma_{N}$ \\
\hline \multirow{5}{*}{2011} & AB40333A-4A & \multirow{3}{*}{6061} & \multirow{2}{*}{ No } & 33 & 18.7 & 12.6 & 7.8 & 6.1 \\
\hline & AB40333A-4C & & & 80 & 2.5 & 1.8 & 1.2 & 0.4 \\
\hline & AB40333A-4D & & Yes & 24 & 2.2 & 1.6 & 1.1 & 0.6 \\
\hline & AB40333A-4B & \multirow{2}{*}{6063} & No & 31 & 2.2 & 1.9 & 1.2 & 0.6 \\
\hline & AB40333A-4F & & Yes & 39 & 3.3 & 1.9 & 1.1 & 0.6 \\
\hline \multirow{5}{*}{2009} & AB40333A-7A & \multirow{3}{*}{6061} & \multirow{2}{*}{ No } & 157 & 1.8 & 1.6 & 0.8 & 0.3 \\
\hline & AB40333A-9C & & & 145 & 4.3 & 2.2 & 0.9 & 0.8 \\
\hline & AB40333A-7D & & Yes & $\mathrm{ND}$ & ND & $\mathrm{ND}$ & ND & ND \\
\hline & AB40333A-7A & \multirow{2}{*}{6063} & $\mathrm{No}$ & 91 & 3.5 & 2.9 & 0.8 & 1.0 \\
\hline & AB40333A-7D & & Yes & ND & ND & ND & ND & ND \\
\hline
\end{tabular}

Prior to discussing the pit depths on the furniture rack coupons, pit depths were also evaluated for the 6063 control coupon that was cleaned in nitric acid for 20 minutes. No pits were found when the coupon was examined at $100 x$ magnification. At $200 x$ magnification, 13 measureable pits were found with an average and maximum pit depth of 0.45 and 0.95 mils, respectively. These pits were angular and asymmetric (not 
rounded) with the long axis running parallel to the grinding marks in many cases as shown in Figure 5-1.

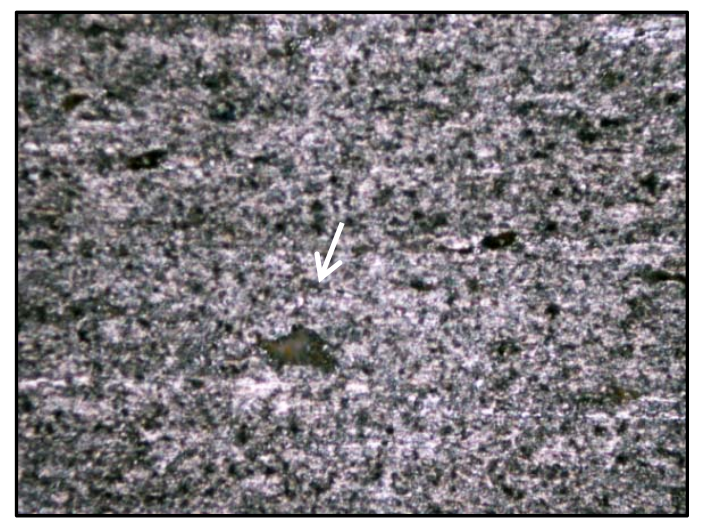

Figure 5-1 Pitting observed in 6063 control coupon cleaned in nitric acid with 2011 furniture rack coupons (200x, arrow indicates pit)

Cleaning will have some impact on the furniture rack coupon data, a slight increase in pit density with depths similar to those measured on the furniture rack coupons. The control coupon did not have established pits so the change in pit depth during cleaning could not be determined. Also the control coupon had a polished surface as opposed to the oxidized surface of the furniture rack coupons. The oxide is expected to slow the degradation and the initiation of pitting during cleaning especially for short cleaning times.

The pitting morphology demonstrated that most pits were not cleaning pits as shown in Figure 5-2. In Figure 5-2 (A), a typical symmetrical, rounded pit was the prevalent pitting observed showing minimal directionality with respect to the grinding marks. Some pits appeared angular and to be growing along the grinding marks as shown in Figure 5-2 (B) and were similar to the control coupon pits (Figure 5-1).

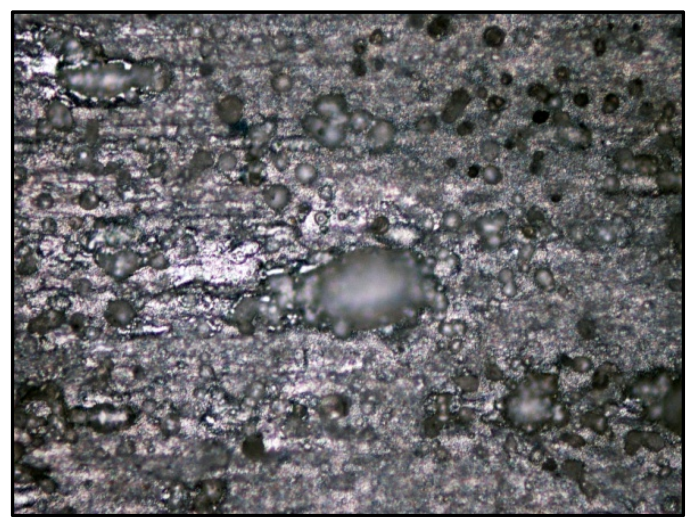

(A)

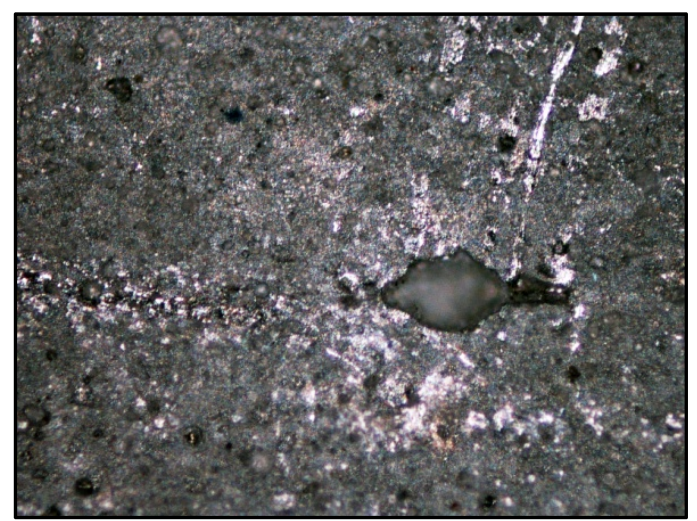

(B)

Figure 5-2 Pit morphologies in 2011 furniture rack coupons after cleaning in nitric acid: (A) rounded, symmetrical pit on AB40333A-4A and (B) angular, directional pit on AB40333A-4B (200x) 
The furniture rack coupons for 2011 had similar pitting parameters except for coupon AB40333A-4A which had some significantly deeper pits as shown by the $\mathrm{P}_{\max }$ and $\mathrm{P}_{10}$ values as well as a larger standard deviation. In general for the 2011 coupons, the pit count was very low which is in agreement with a previous pit density of less than 10 pits $/ \mathrm{m}^{2}$ [3]. The average pit depth, $\mathrm{P}_{\mathrm{N}}$, was approximately 1 mil after approximately 16 years of exposure, which indicates an extremely low average pit growth rate of less than 1 mpy.

Since the furniture rack coupons were strung together in the same location of the basin, pitting differences would be expected to be associated with the plate microstructure (impurities or intermetallics at the surface) and not environmental factors. If coupon $4 \mathrm{~A}$ was located at the top of the coupon string, however, particulate settling on this coupon might be more prevalent and act as precursor to pitting (this type of corrosion is referred to as underdeposit corrosion). Since the coupons were hung vertically, metallurgical differences are more likely. Further metallurgical investigation of coupon 4A would be required to assess the difference in pitting from the other 2011 coupons.

The furniture rack coupons for 2009 had a similar pitting profile with the pit depth parameters being equivalent. These values are in good agreement with those obtained in 2011 except for $\mathrm{P}_{\max }$. The $\mathrm{P}_{\max }$ for 2009 was approximately 4 mils, which is much shallower than that observed in 2011 at 19 mils. The pit density in 2009 was larger than that obtained in 2011, although both are less than $10 \mathrm{pits} / \mathrm{m}^{2}$. Pits in the 2009 furniture rack coupons were more clustered than pits observed in the 2011 coupons.

\subsection{Weld and HAZ}

The measurement of pits in the weld and HAZ of the furniture rack coupons was difficult due to the retained oxide in both these areas for both sets of coupons, 2009 and 2011. The pit depth parameters are summarized in Table 5-1, including the pit count $(\mathrm{N})$, maximum pit depth $\left(\mathrm{P}_{\max }\right.$, mils), the average depth of ten deepest pits $\left(\mathrm{P}_{10}\right.$, mils), the average depth of all pits $\left(\mathrm{P}_{\mathrm{N}}\right.$, mils $)$ and the standard deviation of all the pits depths $\left(\sigma_{\mathrm{N}}\right.$, mils). The standard deviation of the ten deepest pits was similar in most cases to $\sigma_{\mathrm{N}}$. The pit count should not be taken as representative since oxide still covered parts of the weld and HAZ.

Pit measurements on coupon AB40333A-4F were not made because the oxide could not be removed without jeopardizing base metal pit measurements. Additional cleaning is an option, but a further analysis of the cleaning procedure is required as explained in the Discussion section.

From a review of the data, the pit depths in the weld and HAZ are greater for the 2009 coupons than the 2011 coupons as noted by the larger values for $\mathrm{P}_{\max }, \mathrm{P}_{10}$ and $\mathrm{P}_{\mathrm{N}}$. The calculated standard deviations however are similar. The storage rack sample had values that were similar to those pit depths found in the 2009 furniture rack coupons. Cleaning times for the storage rack were approximately 30 minutes and was stopped because the oxide was not easily removed. 
Table 5-2 Pit Depths in the Weld and HAZ of 2009 and 2011 Furniture Rack Coupons*

\begin{tabular}{|c|c|c|c|c|c|c|c|c|}
\hline Year & Number & Alloy & Weld & $\mathbf{N}$ & $\mathbf{P}_{\max }$ & $\mathbf{P}_{\mathbf{1 0}}$ & $\mathbf{P}_{\mathbf{N}}$ & $\sigma_{\mathbf{N}}$ \\
\hline \multirow{3}{*}{2011} & \multirow{2}{*}{ AB40333A-4D } & \multirow{2}{*}{6061} & Weld & 12 & 3.2 & 2.0 & 1.7 & 1.3 \\
\cline { 4 - 9 } & \multirow{2}{*}{ AB40333A-4F } & \multirow{2}{*}{6063} & HAZ & 16 & 1.8 & 1.2 & 1.0 & 0.5 \\
\cline { 4 - 9 } & & Held & ND & ND & ND & ND & ND \\
\hline \multirow{3}{*}{2009} & \multirow{2}{*}{ AB40333A-7D } & \multirow{2}{*}{6061} & Weld & 102 & 7.2 & 5.6 & 3.4 & 1.1 \\
\cline { 4 - 9 } & \multirow{2}{*}{ AB40333A-7D } & \multirow{2}{*}{6063} & HAZ & 47 & 5.6 & 4.5 & 3.3 & 0.9 \\
\cline { 4 - 9 } & & & Weld & 49 & 4.4 & 3.8 & 2.6 & 0.8 \\
\cline { 4 - 9 } & \multirow{2}{*}{ Storage Rack } & \multirow{2}{*}{6063} & Weld & 7 & 4.5 & ND & 2.3 & 1.7 \\
\cline { 4 - 9 } & & HAZ & 74 & 7.2 & 4.8 & 2.3 & 1.3 \\
\hline
\end{tabular}

* ND - no data

A comparison of pit depths to measurements from previous years for the weld and HAZ of 6061 plate and 6063 U-channels are shown in Figures 5-3 and 5-4, respectively. The data indicated that the pitting corrosion in the weld and HAZ appears to be constant over the exposure period with the average pit depth in the range of 3-4 mils. This value is slightly greater than the average depth measured for the base metal at 1-2 mils.

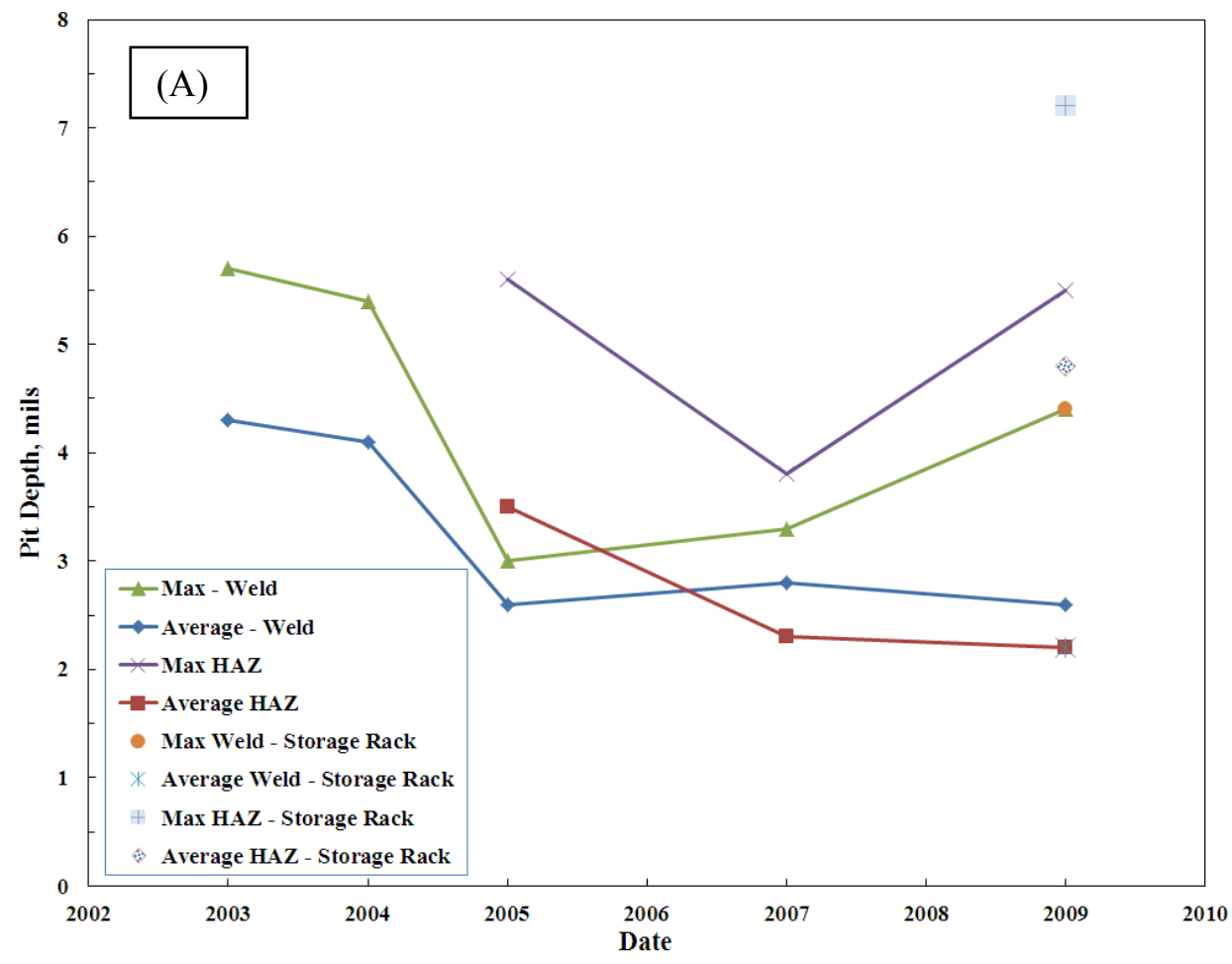

Figure 5-3 Cumulative average and maximum pit depths from the weld and HAZ measured in 6063 U-channel and storage rack 
The maximum pit depth does not appear to be growing, although 2009 data values show an increase. These larger pit depths may be associated with the extended cleaning times. Cleaning times have not been reported previously so the impact on previous data sets cannot be evaluated [1-3].

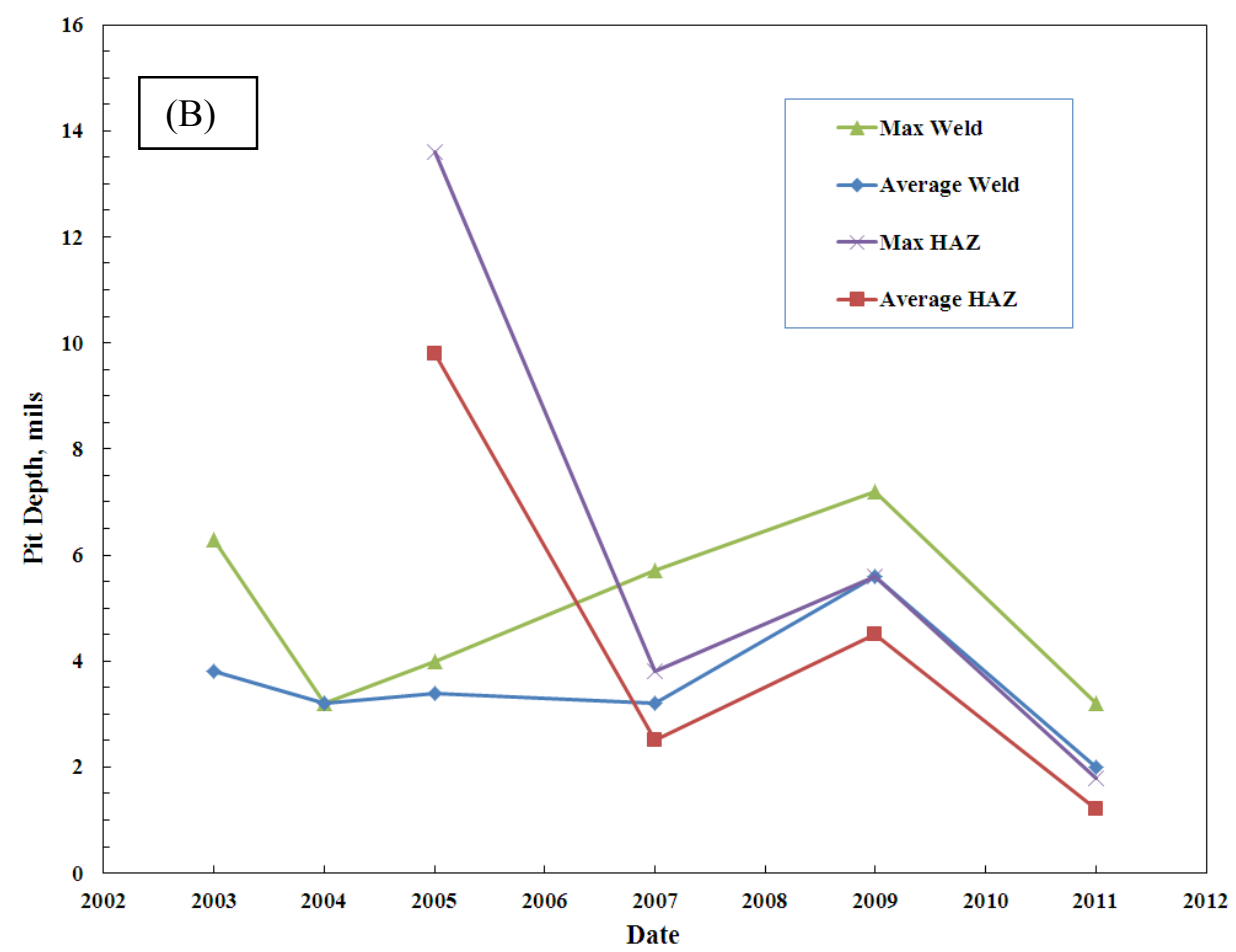

Figure 5-4 Cumulative average and maximum pit depths from the weld and HAZ measured in 6061 plate

\subsection{Discussion}

The corrosion resistance of aluminum alloys is dependent on the buildup of a tenacious uniform oxide. Most of the furniture racks as well as the coupons in the surveillance program had an air-formed oxide $(\sim 5 \mathrm{~nm})$ prior to immersion in the basin $[8,9]$. Prior to cleanup of the basin water, the thin oxide lead to a low pitting resistance especially in comparison to the store fuel, which have a much thicker oxide formed during reactor operation. Since the coupons were fabricated from the same heat and have the same type of oxide as the actual furniture rack samples they provide a good surrogate of the actual furniture rack. The pit depths measured on the storage rack and the welded U-channel and plate coupons are in good agreement as shown by the data in Table 5-2.

The 2009 and 2011 pit depth data from the furniture rack coupons continue to demonstrate that the well-controlled basin water chemistry is not causing aggressive corrosion of the furniture racks. Average pit depths in the base metal are approximately 1-2 mils as shown by the data in Table 5-1 and 3-4 mils for the weld and HAZ as shown by the data in Table 5-2. As noted previously by Vormelker and Murphy [3], the greater pit depths in the HAZ may be associated with a higher concentration of intermetallics in 
the weld and a galvanic difference between the weld, HAZ and base metal. The trending as shown in Figure 5-1 over the last several years has shown a constant average pit depth. Additionally, the pit density remains low.

The maximum pit depth has shown more variability than the average depths, especially for the HAZ. The variability may be associated with the stochastic nature of pitting and the creation of localized conditions that support pitting. As stated by Vormelker and Murphy [3], this variability may be associated with the difficulty of pit measurements in the HAZ.

The coupon cleaning procedure may also be contributing to some of the variability. Historically, the coupons were cleaned with the intent of removing all the oxide. The oxide on any given sample will vary, which was clearly demonstrated by the difference in oxide of the 2009 and 2011 coupons. The 2009 coupons appeared to have a more tenacious oxide which took extended cleaning times to remove. These extended times in nitric acid may allow pit growth in deep pits and may contribute to population of superficial pits $(\sim 1 \mathrm{mil})$ as shown by the pit depth measurements on the 6063 control coupon. The number of measureable pits in the 2009 furniture rack coupons was 3-4 times higher than in 2011 coupons. A closer evaluation of the cleaning procedure is recommended to optimize conditions for accurate pit depth measurements and condition assessment of the coupons.

The pitting observed on the coupons does not appear to be related to microbiological factors. The number of bacteria in the basin has been on a continual decline since 2008 (Figure 3-3). The biodiversity has declined since 2006. However the average pit depths appear to be constant without any pits depths close to penetrating the full thickness of the coupons.

\subsection{Conclusion}

The furniture rack coupon surveillance continues to demonstrate that the well-controlled basin water chemistry has minimized corrosion for the aluminum alloys used to fabricate the basin storage racks. Average pit depths for the 6061 and 6063 base metal are 1-2 mils, while those for the weld and HAZ are 3-4 mils. This lower corrosion resistance of the weld and HAZ is not currently understood nor are methods for minimizing this corrosion. The maximum pit depths in the weld and HAZ continue to show variability during exposure. The cleaning procedure used during the analysis of the coupons may be a contributing factor and should be further evaluated.

\subsection{References}

1. P. R. Vormelker, A. J. Duncan, and D. W. Vinson, "FY 2002/FY2003 Corrosion Surveillance Results for the SRS Basins," WSRC-TR-2003-00548, December 2003

2. P. R. Vormelker, A. J. Duncan, and T. R. Murphy, "FY2004 Corrosion Surveillance Results for L Basin,” WSRC-TR-2005-00067, September 2005 
3. P. R. Vormelker and T. R. Murphy, "FY2005 and FY2007 Furniture Rack Coupon Surveillance Results for L Basin, SRNS-TR-2008-00034, February 2009

4. J. P. Howell and D. Z, Nelson, "Inspection and Analysis of Aluminum Racks in Spent Fuel Storage Basins," Analysis of In-Service Failures \& Advances in Microstructural Characterization, D. O. Northwood et al (eds.), ASM International, Metals Park, OH, 1999

5. P. R. Vormelker and R. W. Deible, "L Basin Corrosion Surveillance Program Plan," SRNL-TR-2009-00140, Rev. 1, September 2009

6. R. W. Deible, "Spent Fuel Storage Basin Water Chemistry Control Program," WSRC-TR-97-0239, Rev. 5, June 2010.

7. C. J. Berry, "Summary of the Microbial Condition of the L-Disassembly Basin Spent Fuel Storage Facility Through July FY08," SRNL-EST-2008-00028, September 2008

8. M. R. Louthan, R. L. Sindelar, N. C. Iyer, H. B. Peacock, "Corrosion of Aluminum Clad Fuel and Target Elements: The Importance of Oxide Films and Irradiation History," Proceedings of the Embedded Topical Meeting on DOE Spent Nuclear Fuel and Fissile Material Management, American Nuclear Society, June 1996

9. R. L. Sindelar and R. W. Deible, "Demonstration of Long-Term Storage Capability for Spent Nuclear Fuel in L Basin", SRNL-STI-2011-00190, April 2011

10. P. R. Vormelker and C. N. Foreman, "FY2008 Corrosion Surveillance Results for L Basin,” SRNL-TR-2009-00256, December 2009 